\title{
Author Correction: CPSF3-dependent pre-mRNA processing as a druggable node in AML and Ewing's sarcoma
}

Nathan T. Ross, Felix Lohmann (D), Seth Carbonneau, Aleem Fazal D, Wilhelm A. Weihofen, Scott Gleim, Michael Salcius, Frederic Sigoillot (D), Martin Henault, Sarah H. Carl D, Juan B. Rodríguez-Molina D , Howard R. Miller (D), Scott M. Brittain, Jason Murphy, Mark Zambrowski, Geoffrey Boynton, Yuan Wang, Aye Chen, Gregory J. Molind ID, Johannes H. Wilbertz, Caroline G. Artus-Revel, Min Jia, Favour A. Akinjiyan D, Jonathan Turner, Judith Knehr, Walter Carbone, Sven Schuierer (D), John S. Reece-Hoyes, Kevin Xie, Chitra Saran (D), Eric T. Williams (D), Guglielmo Roma (D), Matt Spencer, Jeremy Jenkins (D), Elizabeth L. George, Jason R. Thomas, Gregory Michaud (D), Markus Schirle (D), John Tallarico (D), Lori A. Passmore (iD, Jeffrey A. Chao (D) and Rohan E. J. Beckwith (D)

Correction to: Nature Chemical Biology https://doi.org/10.1038/s41589-019-0424-1, published online 9 December 2019

In the version of the article originally published, two colleagues were omitted from the Acknowledgements section. The section should read "We thank H. Großhans, T. S. Miki, D. Porter, R. Tiedt, J. Baryza and G. Rice for helpful discussions through the course of this research study. This work was supported by the Novartis Research Foundation (J.A.C.), the SNF-NCCR RNA \& Disease network (J.A.C.) and the Medical Research Council (MRC) grant no. MC_U105192715 (L.A.P.)". The error has been corrected in the HTML and PDF versions of the paper.

Published online: 4 March 2020

https://doi.org/10.1038/s41589-020-0508-y

(c) The Author(s), under exclusive licence to Springer Nature America, Inc. 2020

\section{Publisher Correction: An efficient gene knock-in strategy using 5'-modified double-stranded DNA donors with short homology arms}

Yi Yu, Yijun Guo, Qiqi Tian, Yuanqing Lan, Hugh Yeh, Meng Zhang (D), Ipek Tasan, Surbhi Jain and Huimin Zhao iD

Correction to: Nature Chemical Biology https://doi.org/10.1038/s41589-019-0432-1, published online 23 December 2019

In the version of this article originally published, the $x$-axis labels of Fig. $2 \mathrm{~g}$ and $2 \mathrm{~h}$ were switched. The $x$-axis label of $2 \mathrm{~g}$ should read 'GAPDH-EGFP' and that of $2 \mathrm{~h}$ should read 'Lamin A/C-EGFP'. Additionally, the labels for genes AAVS1 and CCR5 in Fig. 2c should be italicized. The errors have been corrected in the HTML and PDF versions of the paper.

Published online: 15 January 2020

https://doi.org/10.1038/s41589-020-0470-8

(C) The Author(s), under exclusive licence to Springer Nature America, Inc. 2020 